Int. J. Dev. Biol. 54: 1659-1670 (2010)

doi: $10.1387 / \mathrm{ijdb} .103202 \mathrm{rk}$

\title{
Role of mitochondrial DNA replication during differentiation of reprogrammed stem cells
}

\author{
RICHARD D.W. KELLY and JUSTIN C. ST. JOHN* \\ Centre for Reproduction and Development, Monash Institute of Medical Research, \\ Monash University, Clayton, Australia
}

\begin{abstract}
Mitochondrial DNA (mtDNA) is a $16.6 \mathrm{~kb}$ genome that encodes for 13 of the 100+ subunits of the electron transfer chain (ETC), whilst the other subunits are encoded by chromosomal DNA. The ETC is responsible for the generation of the majority of cellular ATP through the process of oxidative phosphorylation (OXPHOS). mtDNA is normally inherited from the population present in the mature oocyte just prior to fertilisation. However, following somatic cell nuclear transfer (SCNT), mtDNA can be transmitted from both the donor cell and the recipient oocyte. This heteroplasmic transmission of mtDNA is a random event and does not appear to be related to the amount of mtDNA contributed by the donor cell. The distribution of mtDNA is randomly segregated between blastomeres and differentiating tissues, and therefore the mtDNA complement transmitted to offspring tissue cannot be predicted. mtDNA divergence between the cytoplast and the donor cell in intra- and inter-specific crosses favours a slightly more diverse mtDNA haplotype. However, this is limited as interspecies SCNT (iSCNT) genetic divergence contributes to developmental failure. SCNT embryos demonstrate a plethora of aberrantly reprogrammed characteristics including the uncoordinated regulation of the mtDNA replication factors. This results in increased mtDNA copy number during preimplantation development and propagates the replication of donor cell mtDNA. These failures are likely to be a consequence of incompatible nuclear- and mtDNA -encoded proteins interacting within the ETC thus reducing ATP production. The outcomes would be similar to the severely debilitating or even fatal mtDNA diseases associated with genetic rearrangements to mtDNA or mtDNA depletion type syndromes and have serious implications for any form of karyoplast transfer approach. The only method to overcome the problems of heteroplasmy in SCNT embryos is to completely deplete the donor cell of its mtDNA prior to SCNT.
\end{abstract}

KEY WORDS: mitochondria, mtDNA, somatic cell nuclear transfer, oxidative phosphorylation

\section{Introduction}

Somatic cell nuclear transfer (SCNT) offers a technological approach to studying the biochemical and molecular dynamics of development as well as offering the propagation of desirable genetic traits (Bowles et al. 2007a), preservation of endangered species (Loi et al. 2001) and the derivation of patient specific stem cells through intra- and interspecies SCNT (iSCNT; (St John and Lovell-Badge 2007; St John et al. 2008). The development rates for these SCNT embryos is extremely poor and many factors have been attributed to developmental failures, most notably nuclear reprogramming. Furthermore, the amalgamation of genetically divergent mitochondria from different breeds or species may have deleterious implications and deserves extensive experimentation considering the dynamic functions of mitochondria during development as well as the implicated technological and therapeutic applications of SCNT. To this extent, defective interactions between the donor chromosomally-encoded mitochondrial DNA (mtDNA) transcriptional and replication factors with recipient oocyte mtDNA would result in compromised expression of mitochondrial proteins and propagation of mitochondrial genes. This,

Abbreviations used in this paper: ETC, electron transfer chain; mtDNA, mitochondrial DNA; OXPHOS, oxidative phosphorylation; PGC, primordial germ cell; POLGA, polymerase gamma; SCNT, somatic cell nuclear transfer.

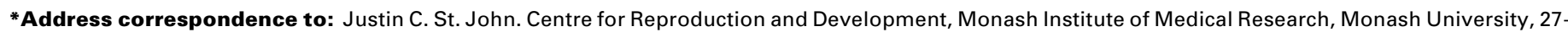
31 Wright Street, Clayton, VIC 3168, Australia. Fax: + 61 (03) 9594-7416. e-mail: justin.stjohn@monash.edu
} 
in turn, would compromise the given cellular demand for ATP generated through oxidative phosphorylation (OXPHOS) thus potentially triggering embryonic arrest or subsequent disease phenotypes (Wallace 2005; Wallace et al. 2010). Ineffective interactions of the chromosomally- and mtDNA-encoded complexes of the electron transport chain (ETC) could also result in deleterious phenotypes pre- and post-term. Indeed, SCNT embryos (Alexopoulos et al. 2008), foetuses (Hiendleder et al. 2003; Burgstaller et al. 2007) and offspring (Steinborn et al. 1998; Hiendleder et al. 1999; Meirelles et al. 2001; Takeda et al. 2003) can exhibit different mitochondrial profiles, which has been suggested to be a common cause of premature death resulting from reproductive cloning (St John 2002). The aim of this review is to describe and discuss these outcomes.

\section{Mitochondria}

Along with energy production, mitochondria are involved in the regulation of steroidogenesis (Bose et al. 2002), reactive oxygen species (ROS; (Nemoto et al. 2000), nitric oxide (Dedkova et al. 2004), calcium signalling (Brini 2003; Dumollard et al. 2006); and apoptosis (Joza et al. 2001). The eukaryotic mitochondrion most likely originated from $\alpha$-protobacterium, an event that took place approximately 1 to 2 billion years ago. Over hundreds of millions of years, an endo-symbiotic relationship evolved, whereby key proto-mitochondrial genes, located on a circular genome within the mitochondria, were transferred to the eukaryotic chromosomal genome (Gray et al. 1999). As a result, the mammalian chromosomal genome contains many of the genes encoding for each of the complexes of the electron transfer chain (ETC) along with nearly all the necessary proteins for the transcription and replication of mtDNA, along with numerous factors involved in protein translation of the mitochondrial genes (Lang et al. 1999; Andersson et al. 2003).

\section{Mitochondrial DNA}

The double stranded mammalian mtDNA is between 16.2 and $16.7 \mathrm{~kb}$ in size (see Fig. 1) and encodes 13 of the 100+ subunits of the electron transfer chain (ETC; See Fig. 2; Anderson et al. 1981; Bibb et al. 1981; Anderson et al. 1982; Ursing and Arnason 1998) 2 rRNAs and 22 tRNAs that flank most of the coding genes. The ETC is an intra-mitochondrial apparatus that generates the vast majority of cellular ATP through the process of OXPHOS (Wallace et al. 2010). OXPHOS, an aerobic mechanism, is by far the most efficient process for generating ATP as it produces $32 \mathrm{~mol}$ ecules to every 2 generated through glycolysis, an anaerobic form of metabolism (Brown 1992; Pfeiffer et al. 2001). Consequently, OXPHOS is essential for aerobic cells, such as neurons, cardiomyocytes and oxidative skeletal muscle, which have high energy demands, to mediate their complex cellular functions, such as maintaining heartbeat through pacemaker cells or initiating and driving action potentials (Erecinska and Silver 1989; Wong-Riley 1989; Heineman and Balaban 1990). The importance of these genes in maintaining vital cellular functions is demonstrated by mutations and deletions, which can result in severe cellular impairment or can be lethal (Wallace 1999).

\section{mtDNA replication}

Whilst the mitochondrial genome is not interspersed with introns and exons as for the chromosomal genome, it has one non-coding region, the displacement or D-Loop (see Fig. 1). This is the site of interaction of several nuclear-encoded mtDNAspecific transcription and replication factors that mediate mtDNA replication (Anderson et al. 1981; Anderson et al. 1982; Shadel and Clayton 1996; Shadel and Clayton 1997). Mitochondrial transcription factor A (TFAM) binds to the enhancer of the Light Strand Promoter within the D-Loop to induce structural changes that expose the promoter region to the mitochondrial-specific RNA polymerase (Falkenberg et al. 2007). This allows an RNADNA hybrid primer to be generated, which is then used by the mitochondrial specific DNA Polymerase Gamma (POLGA) to initiate replication (Fisher and Clayton 1985; $\mathrm{Xu}$ and Clayton 1992). POLGA is supported by its accessory subunit, POLGB, the mitochondrial single-stranded DNA-binding protein (mtSSB) and the helicase, Twinkle (Korhonen et al. 2003). Decreased expression and mutation to the mtDNA replication factors result in fewer genomes being available for transcription and mediate the onset of mtDNA depletion syndromes (Copeland 2008).

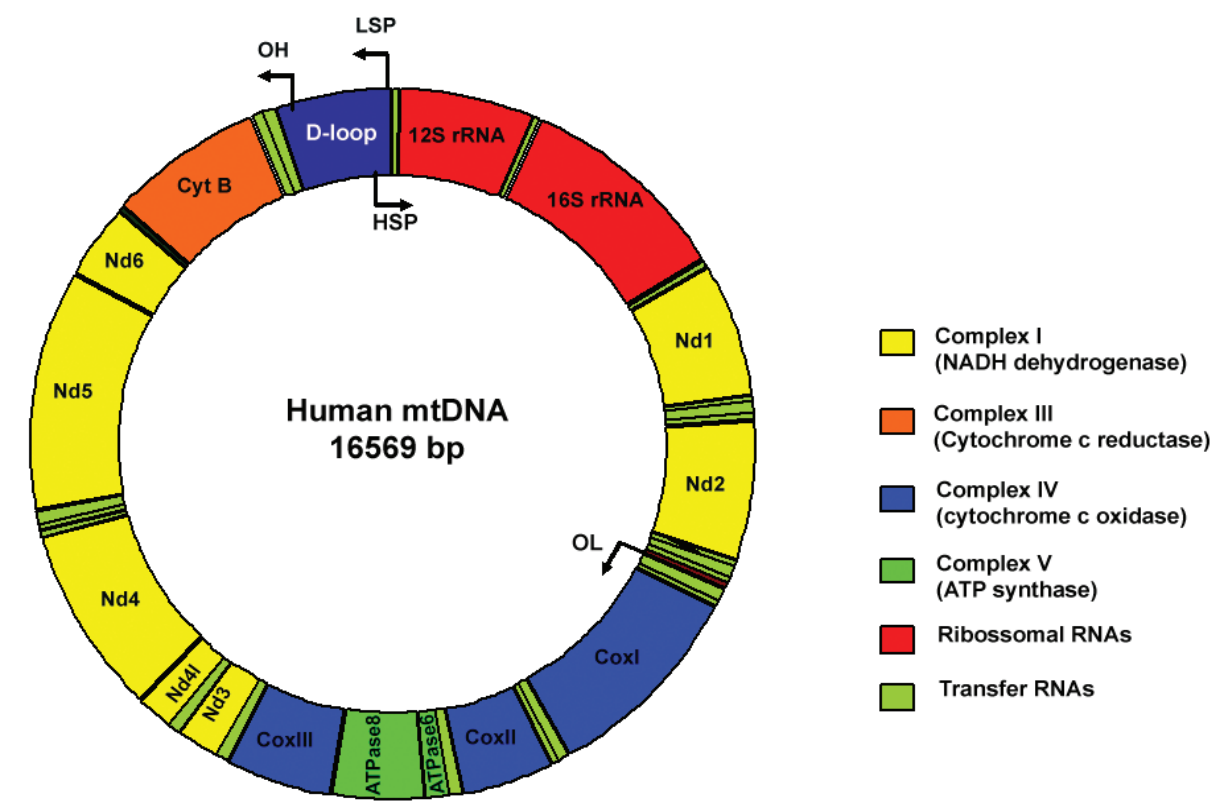

Fig.1. The mammalian mtDNA genome encodes 13 of the subunits of the electron transfer chain (ETC). For Complex I, these consists of ND 1, 2, 3, 4, 4L, 5 and 6); Complex III (CytB); Complex IV (COXI, II and III); and Complex V (ATPase6 and ATPase8). mtDNA also encodes two rRNAs (12S and 16S rRNAs) and 22 tRNAs. The D-loop is the main control region, which houses the $\mathrm{H}$-strand promoter region (HSP), the L-strand promoter region (LSP), and the origin of $\mathrm{H}$ strand replication $\left(\mathrm{O}_{H}\right)$. A second control region, consisting of only $30 \mathrm{bp}$, is located between ND2 and $C O X I$ and is the site of the origin of L-strand replication $\left(O_{L}\right)$. 
Two methods have been described to explain mtDNA replication. The assymetric model proposes that replication is initiated from the origin of $\mathrm{H}$-strand replication, located within the D-Loop region, and continues two-thirds round the genome to the origin of L-strand replication (Shadel and Clayton 1997). L-strand synthesis then proceeds in the opposite direction. The coupled leading-and lagging-strand synthesis model suggests that both $H$ and $L$ strands are replicated bidirectionally from the same initiation cluster site (Yasukawa et al. 2005; Yasukawa et al. 2006). This mechanism is proposed to occur in addition to the asymmetric model, but is typical of cells repopulating mtDNA.

\section{Maternal inheritance of mtDNA}

Mitochondrial DNA (mtDNA) is normally inherited unimaternally with all copies being identical (homoplasmy; Birky, 1995; Birky, 2001). This population originates from approximately 200 copies present in each primordial germ cell (PGC), which are laid just after gastrulation (Shoubridge 2000; Shoubridge and Wai 2007). Although this tends to be true for intra-specific crosses, sperm mtDNA can be transmitted through inter-specific crosses generated with gametes from different breeds or strains (Lansman et al. 1983; Gyllensten et al. 1991). In intra-specific crosses, sperm mitochondria are selectively ubiquitinated within the fertilized oocyte just prior to the onset of embryonic genome activation (EGA) demonstrating that this is an oocyte rather than embryo mediated event. This prevents the potential transmission of sperm mtDNA during subsequent development (Sutovsky et al. 1999; Sutovsky et al. 2000). This ubiquitinated-targetted process does not regulate sperm mtDNA transmission in interspecific crosses resulting in variable transmission to offspring. However, sperm mtDNA does not appear to be fixed in the germ line, as subsequent generations do not inherit this paternal source of mtDNA.

\section{mtDNA and developmental competence}

The mitochondria of the mature metaphase II (MII) oocyte contain only a single mtDNA copy (Satoh and Kuroiwa 1991), but have significantly more mitochondria present meaning a total mtDNA content that is at least a 10-fold higher than that of somatic cells. Thus, mtDNA potentially contributes to $\sim 50 \%$ of the total DNA present in the oocyte at fertilization (Reynier et al. 2001). The number of mtDNA copies present in mature mammalian oocytes is on average greater than $1 \times 10^{5}$ copies although mtDNA copy number varies dramatically between oocytes and between mammalian species. The mechanisms of these variations and the purpose of high copy numbers at fertilization have been matters of great debate recently.

It has been demonstrated that oocytes with higher copy numbers of mtDNA are thought to be associated with higher fertilisation rates. Glucose-6-phosphate dehydrogenase (G6PD) is a metabolic enzyme involved in the pentose phosphate pathway, and is essential for cellular growth (Tian et al. 1998). G6PD breaks down Brilliant cresyl blue (BCB) dye, which has been applied in the determination of oocyte developmental competence (RodriguezGonzalez et al. 2002; El Shourbagy et al. 2006). Fully matured oocytes have decreased G6PD activity and stain blue $\left(\mathrm{BCB}^{+}\right)$, suggesting developmental competence. Increased G6PD activity reduces $B C B$ to a colourless compound ( $\mathrm{BCB}^{-}$) and has been associated with reduced fertilisation rates (Rodriguez-Gonzalez et al. 2002). In the pig, competent $\mathrm{BCB}^{+}$oocytes contain more copies of mtDNA, and are more likely to fertilize than incompetent BCB- oocytes (EI Shourbagy et al. 2006). In addition, supplementation of $\mathrm{BCB}^{-}$oocytes with purified populations of mitochondria from $\mathrm{BCB}^{+}$oocytes improved subsequent developmental competence post-fertilization (El Shourbagy et al. 2006). Indeed, human (Reynier et al.2001; Santos et al. 2006) and bovine (May-Panloup et al. 2005a; Hua et al. 2007) oocytes with higher copy numbers are associated with increased in vitro developmental rates. Previously, a threshold of 100,000 mtDNA copies was hypothesised for developmental competence (Piko and Taylor 1987; Reynier et al. 2001). However, a recent report by Wai et al. (2010) demonstrated through heterozygous Tfam knockout mice that oocytes with as few as 4,000 mtDNA copies could be fertilized and develop to the blastocyst stage, although a minimum of 50,000 copies in mature oocytes was a critical threshold for subsequent postimplantation development (Wai et al. 2010). Nevertheless, Tfam heterozygous offspring display respiratory chain deficiency in the heart resulting in a cardiomyopathy phenotype (Larsson et al. 1998; Wredenberg et al. 2002). Their homozygous counterparts die prior to embryonic day $(E) 10.5$, which clearly suggests that high numbers of mtDNA copy in the MII oocyte represent an investment in the long term survival of the subsequent offspring (Larsson et al. 1998). Furthermore, the considerable increase in mtDNA copy number as oocytes mature to MII indicates that an increase in mitochondria is required to provide sufficient energy 
resource to support the multiple intracellular events that take place as fertilisation is initiated and ensues.

MtDNA present in MII occytes is believed to support embryo development to cavitation, after which glycolysis becomes increasingly important in many species (Leese and Lenton 1990; Brison and Leese 1991; Leese et al. 1993; Brison et al. 1993; Houghton et al. 1996; Thompson et al. 1996; Sturmey and Leese 2003; Houghton 2006). Furthermore, the 100,000 minimum copy number may be essential as it has been hypothesised that a threshold level of ATP is required which will synchronise mitochondrial events that support cell division (van Blerkom, 2000; van Blerkom et al. 2000). To this extent, following fertilisation, the totipotent zygote undergoes numerous cell divisions to form the pluripotent blastocyst, randomly segregating the maternal inherited genome between blastomeres with a progressive reduction in mitochondrial content per blastomere. This pattern is observed in all mammalian species so far studied until mtDNA replication is initiated at the blastocyst stage (Shoubridge 2000; Thundathil et al. 2005; May-Panloup et al. 2005b; Spikings et al. 2007). This replication event is most probably restricted to the trophectoderm cells whilst the inner cell mass (ICM) cells have very few mtDNA copies per cell (Cao et al. 2007) and exhibit little expression for POLGA (Spikings et al. 2007; Bowles et al. 2007b). Indeed, during the early cleavage stages, mammalian embryos express very low levels of or no mtDNA replication factor activity (Thundathil et al. 2005; May-Panloup et al. 2005b; Spikings et al. 2007; Bowles et al. 2007b). A small replication event has been described between the pronuclear and the 2-cell stage in mouse embryos, indicating replenishment rather than an increase in mtDNA copies as there was no significant change in mtDNA copy number (McConnell and Petrie 2004). Similar outcomes have been identified in porcine (Spikings et al. 2007) and ovine (Bowles et al. 2007b) embryos. Interestingly, mouse preimplantation development up to the morula stage is characterised by consistent levels of mtDNA copy number (Thundathil et al. 2005). However, porcine (Spikings et al. 2007) and bovine embryos (May-Panloup et al. 2005b) demonstrate a reduction in total embryo mtDNA copy number, suggesting a programmed elimination of mtDNA and/or mitochondria.

Some mtDNA and mitochondria during development will be lost through the occurrence of apoptosis in individual blastomeres. Apoptosis in embryonic cells is a potential indicator of a cellular response to suboptimal conditions, although chromosomal abnormalities, imbalance of growth factors, reactive oxygen species (ROS) and other damaging factors cause cell death (reviewed in Fabian et al. 2005). Apoptosis is normally first observed postcompaction in human embryos (Hardy 1999), at the blastocyst stage in mouse (Kamjoo et al. 2002) and porcine embryos (Hao et al. 2003; Hao et al. 2004), whilst in bovine embryos the first occurrence is at the 8-16 cell stage (Matwee et al. 2000; Gjorret et al. 2007). The apoptotic process can be triggered by staurosporine treatment in murine (Weil et al. 1996) and bovine (Matwee et al. 2000) embryos during early cleavage stages prior to EGA. In SCNT and iSCNT embryos, the incidence of apoptosis is increased compared to their in vitro fertilised and in vivo counterparts (Maddox-Hyttell et al. 2003), which could be a result of the heightened sensitivity of SCNT embryos to suboptimal culture conditions (reviewed in Campbell et al. 2007) along with the mixing of somatic and oocyte mitochondria within the oocyte's cytoplasm. Therefore, programmed cell death (PCD) events during development have the potential to eliminate blastomeres at varying stages, which could potentially result in reduced total embryo mtDNA copy number. However, this is unlikely to be the active mechanism for reducing mtDNA copy number in bovine and porcine embryos as the apoptotic events occur post-16 cell stage at which point copy number has already significantly decreased. As discussed earlier, the embryo does have the capacity to target mitochondria for destruction as evidenced by spermmitochondrial specific elimination. The programmed elimination of mtDNA during preimplantation, either recipient or donor in origin, is a mechanism which has yet to be described.

\section{Mixing of somatic and oocyte mitochondria: implica- tions for development}

A mitochondrial morphological-functional relationship in preimplantation embryos has yet to be fully explored although an elongated phenotype and developed transverse cristae are considered to be characteristic of fully functional mature mitochondria capable of producing ATP through the oxidation of various substrates (Mannella 2006). Ultrastructural analysis of mammalian oocytes and embryos has identified numerous mitochondrial morphologies with some differences observed between species. However, mammalian oocytes generally contain spherical immature mitochondria, which are characterised by electron dense matrices with few or no cristae (Hillman and Tasca 1969; Hillman and Hillman 1975; King et al. 1996). As development progresses mitochondrial differentiation is observed during progressive cleavages to an elongated shape, with reduced electron density and transverse cristae observed at the blastocyst stage (Van et al. 1990; Plante and King 1994; King et al. 1996; Crosier et al. 2000; Crosier et al. 2001; Tao et al. 2008). These structural changes are associated with increased metabolic activity, oxygen consumption and $\mathrm{CO}_{2}$ production observed in the blastocyst (Thompson et al. 1996; Barnett and Bavister 1996).

Nuclear transfer embryos display numerous ultrastructural changes compared to in vitro produced (IVP) and in vivo embryos (King et al. 1996). Nuclear transfer embryos produced using embryonic (King et al. 1996), foetal (Zhong et al. 2007; Zhong et al. 2008) or adult (Tao et al. 2008; Han et al. 2008) donor cells demonstrate heterogenous morphologies not seen in IVP or in vivo embryos that persist for several cleavages. The dynamic changes of mitochondrial structure, typical of preimplantation development, is maintained in nuclear transfer embryos. In human (Motta et al. 2000), pig (Katayama et al. 2006), primate (Squirrell et al. 2003) and hamster IVF embryos (Bavister and Squirrell 2000), perinuclear aggregation of mitochondrial is observed during early cleavage stages and this may be associated with developmental competence (Au et al. 2005). This cellular ability to translocate to perinuclear regions is reduced in porcine SCNT embryos due to the absence of factors derived from the sperm and oocyte spindles (Katayama et al. 2006). Mixing of mature somatic and immature oocyte mitochondria at reconstruction may be deleterious to successful development, although more sophisticated analysis is required. The additional dysfunctional translocation of mitochondria during early cleavage stages could also contribute to the subsequent failures that are characteristic of SCNT. 
Although oxygen consumption remains relatively constant until an increase at the blastocyst stage, in general embryos throughout mammalian preimplantation development are reliant on OXPHOS for the generation of ATP, most probably to fuel cellular proliferation (Houghton et al. 1996; Thompson et al. 1996; Sturmey and Leese 2003). Mouse embryos depend entirely on OXPHOS until the blastocyst stage at which embryos start to metabolise glucose (Houghton et al. 1996). Glucose is however metabolised in human (Gott et al. 1990), ovine (Thompson et al. 1991; Thompson et al. 1992; Thompson et al. 1993), porcine (Sturmey and Leese 2003) and bovine (Thompson et al. 2000) embryos pre-compaction suggesting that they are not entirely reliant on OXPHOS. Furthermore, there is a metabolic switch to increase ATP production from glycolysis during compaction and blastulation (reviewed in Barnett and Bavister 1996). Cloned mouse embryos display irregular substrate requirements compared to IVF and in vivo embryos (Heindryckx et al. 2001; Chung et al. 2002; Gao et al. 2003; Han et al. 2008). Cumulus cell clones (Chung et al. 2002; Han et al. 2008) have a preference for glucose containing media as early as the 1-cell stage, which enhances development to the blastocyst stage. In addition, SCNT embryos produced using myoblast donor cells fail to thrive in standard embryo culture media, but flourish in somatic media favoured by the original donor cells (Gao et al. 2003). These cloned embryos continued to express the somatic glucose transporter Glut-4, indicating inadequate reprogramming of the somatic genome and that the somatic genome significantly modifies the embryos metabolic phenotype. These findings highlight the essential requirement for nuclear-cytoplasmic compatibility during development, which in some cases seems to be absent in cloned embryos. However, any links between developmental competence, perturbed metabolic output and disrupted phenotypes characteristic of SCNT embryos have yet to be elucidated.

\section{Transmission of mtDNA following SCNT: homoplasmy or heteroplasmy}

Somatic cells contain from a few hundred up to several thousand mitochondria each containing between two and ten copies of mtDNA (Michaels et al. 1982) reflecting the cells requirement for ATP (Moyes et al. 1998; Moyes 2003). Indeed, fully differentiated cells, such as skeletal and cardiac muscle cells possess $3,650 \pm 620$ and 6,790 $\pm 920 \mathrm{mtDNA}$ copies/cell, respectively (Miller et al. 2003), whilst sheep fetal fibroblasts (SFF; (Bowles et al. 2007b) and mouse embryonic fibroblasts (MEFs; Kelly et al. Manuscript in preparation) contain $4241 \pm 411$ and $807 \pm 21.8$ copies per cell, respectively. Oocyte mitochondria contain very few cristae, which are the inner membrane invaginations that harbour the five multimeric protein complexes of the ETC. Cristae increase the surface area of the inner mitochondrial membrane and are therefore abundant in mitochondria from highly aerobic and energy-demanding somatic tissues. Ultrastructural analysis of MII oocyte mitochondria shows an immature spherical structure of arched cristae and a dense matrix, suggesting a restricted capacity for ATP production via OXPHOS (Wassarman and Josefowicz 1978; Au et al. 2005; Ramalho-Santos et al. 2009). Somatic mitochondria are highly metabolically active and proactively undergo mitochondrial biogenesis (Moyes 2003; Nisoli et al. 2004). Thus, the introduction of mature somatic mitochondria into a mitochondrial quiescent environment has the potential to influence cellular metabolic function and subsequent developmental competence. Following fusion and activation, the reconstructed embryo is heteroplasmic for two mitochondria haplotypes, although the somatic-oocyte ratio at reconstruction is less than $0.01 \%$. Paternal mitochondria are normally degraded during preimplantation development, although one exception has been documented in a male patient suffering from a mitochondrial myopathy, originating from a $2 \mathrm{bp}$ deletion in his father's sperm. In this instance, at fertilisation, heteroplasmy of less $0.005 \%$ contributed to a muscle disease phenotype with $90 \%$ mutant mitochondrial loading in adult tissue (Schwartz and Vissing 2002). Indeed, a similar outcome can take place when karyoplasts are transferred to mammalian oocytes, whether using somatic cells, pronuclei or MII spindles, with the potential transfer of mitochondria above threshold levels for the elimination of subsequent disease phenotypes in cloned foetuses and offspring (St John and Campbell 2010).

Following reconstruction during NT, the resultant embryo is potentially heteroplasmic (St John et al. 2005) for donor (somatic or embryonic) and recipient (oocyte) mtDNA. The genetic profiles of such clones results in either the elimination of donor mtDNA during gestation leading to offspring being homoplasmic (Evans et al. 1999) or the persistence of donor mtDNA and then being heteroplasmic for the transmission of both donor and recipient oocyte mtDNA (Hiendleder et al. 1999; Takeda et al. 1999; Meirelles et al. 2001; Steinborn et al. 2002; Takeda et al. 2003; St John et al. 2005). Thus, the offspring are authentic nuclear clones but genetic hybrids. The generation of heteroplasmic offspring may also be true for assisted reproductive techniques such as cytoplasmic transfer (St John and Barratt 1997; Brenner et al. 2000; St John 2002; St2002), embryonic cell NT (ECNT; (Steinborn et al. 1998; St John and Schatten 2004), MII spindle transfer (St John and Campbell 2010) and pronuclear transfer (Craven et al. 2010). Application of these techniques for improved reproductive success or for the prevention of disease transmission to offspring requires vigilant analysis of the transferred genetic material, since heteroplasmy of $0.01 \%$ at the pronuclear stage could result in (an) adult disease phenotype(s) (Schwartz and Vissing 2002).

Numerous studies have analysed the heteroplasmic nature of cloned embryos during preimplantation development. Persistence of donor mtDNA is observed in SCNT (Do et al. 2002; Bowles et al. 2008) and interspecies SCNT (iSCNT; (Yang et al. 2003; Hua et al. 2008; Ma et al. 2008) and ranges from 0\% to $69 \%$ during preimplantation development. Transmission of mtDNA to cloned offspring is extremely important for the production of interspecies SCNT embryos and the derivation of patient specific embryonic stem cells (ESCs; (St. John and Lovell-Badge 2007). The contributions of donor and recipient DNA detected in individual offspring derived by nuclear transfer varies considerably with reported contributions of donor mtDNA ranging from $0 \%$ in ovine (Evans et al. 1999) to 59\% in cattle (Steinborn et al. 1998; Hiendleder et al. 1999; Meirelles et al. 2001; Takeda et al. 2003).

\section{Genetic diversity}

Differences in mtDNA sequence between donor cell and recipient oocyte are likely to give rise to proteins with slight differences in their respective amino acid sequences (St John et al. 2005). This is likely to result in inadequate interaction between the 


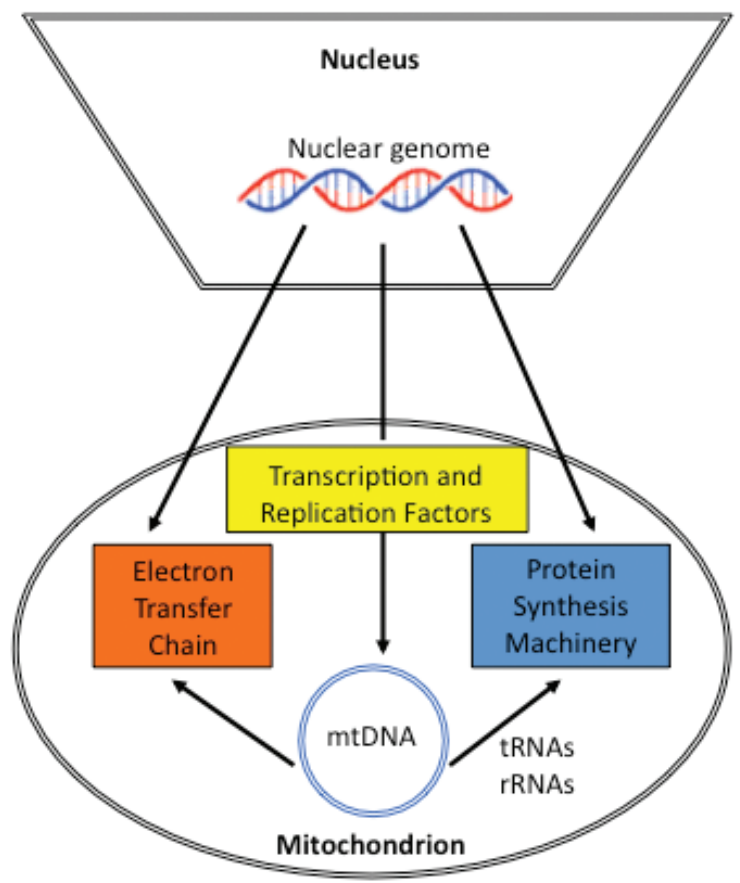

Fig. 3. Nucleo-mitochondrial interactions. The mitochondrial genome is dependent on nuclear-encoded transcription, replication and translation factors for its propagation and to generate proteins, which contribute to the ETC. The contribution of proteins to the ETC provides cellular energy to ensure that nuclear DNA can be replicated and transcribed and mediates its epigenetic regulation, thus ensuring lineage specific gene expression.

individual ETC subunits, which might lead to reduced oxidative capacity and consequently embryonic or foetal death due to the failure to maintain the symbiotic relationship between the nucleus and the mitochondria (see Fig. 3). Studies have demonstrated the effects of mtDNA haplotypes between different breeds of cattle where they have the potential to produce greater numbers of blastocysts following SCNT (Bruggerhoff et al. 2002) and improve developmental competence of IVF embryos (Tamassia et al. 2004), possibly via epigenetic mechanisms (Yan et al. 2010). The degree of genetic divergence between recipient and donor cell mtDNA permitted for ovine blastocyst development is $0.0391 \%$ (Loi et al. 1998) whilst for the production of cloned cattle up to $0.0787 \%$ is tolerable (Bowles et al. 2008). However, a 4-fold increase (mean $=0.4114 \%$ ) in genetic divergence, by generating caprine-ovine clones, has demonstrated the failure of such embryos to develop to the blastocyst stage (Bowles et al. 2007b). Interestingly, the donor cell favours a genetically more diverse mtDNA haplotype to that of its own with the most divergent genetic distance being at $0.0787 \%$. Fusion between very close genetic partners appears to hinder development. Fig. 4 demonstrates the potential relationship between the mtDNA genetic donor cells and recipient oocytes.

\section{Lessons from genetic diversity in somatic-cell fusions}

The effects of diverse nuclear-mitochondrial communication are demonstrated by interspecies cybrid fusion models of human disease. Fusion of Orang-utan (Pongo pygmaeus) with human
mtDNA-less cells (Kenyon and Moraes, 1997), Chimpanzee (Pan troglodytes) with gorilla (Gorilla-gorilla) cells (Barrientos et al. 1998) or rat (Rattus rattus) with mtDNA-less mouse (Mus musculus) cells results in compromised respiratory capacity due to inadequate interaction of the ETC subunits. Although the direct role of mitochondrial-nuclear dysfunction in SCNT embryos remains to be elucidated, there is some evidence to demonstrate that somatic cell mitochondria adversely affect embryonic development. For example, development rates to blastocyst of parthenogenetically activated oocytes supplemented with somatic mitochondria are lower compared to non-supplemented controls (Takeda et al. 2005). Heteroplasmic mice produced by cytoplasmic transfer, where two distant populations of mtDNA are present, demonstrate numerous physiological abnormalities including systemic and pulmonary hypertension, increased body mass and abnormalities associated with electrolytes and haematological parameters (Acton et al. 2007). The increased genetic distance between the two populations of mtDNA would result in different amino acids being encoded thus mimicking mtDNA type disease.

\section{Lessons from mitochondrial haplotypes and disease}

Many mitochondrial diseases are caused by genetic defects to the mitochondrial genome, which can be either spontaneous or maternally inherited. On the other hand, mutations to chromosomally-encoded ETC genes are inherited in Mendelian fashion. In both cases, these result in the disruption of protein complexes involved in mitochondrial transcription, replication and energetics (DiMauro and Schon 2001; Copeland 2008; DiMauro and Schon 2008). Mitochondrial disorders preferentially affect tissues with high energy demands and thus have been implicated in forms of blindness, deafness, movement disorders, dementias, cardiomyography, myopathy, renal dysfunction and aging (Wallace and Murdock 1999). The epidemiological frequency of disease phenotypes is believed to be approximately 1 in 5000 although mutations have been detected at 1 in 200 in newborn umbilical cords (Schaefer et al. 2004; Schaefer et al. 2008). The conse-

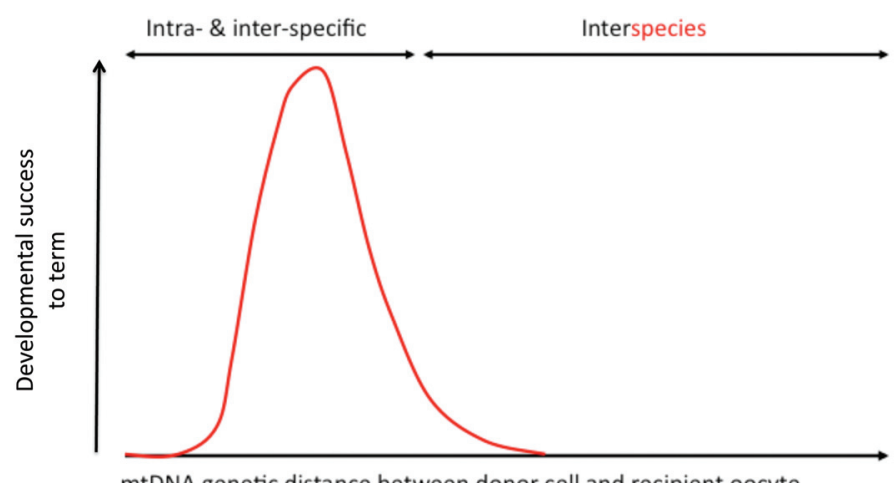

Fig. 4. The role of mitochondrial genetic distance in SCNT outcome. The degree of genetic distance between the donor cell and recipient oocyte is a key determiner for successful preimplantation development and to term. Increasing the genetic distance between two genetic sources enhances developmental outcome. Whilst the optimal genetic distance is within the same species, once the species barrier is crossed, there is significantly reduced developmental outcome. Red represents same species. 


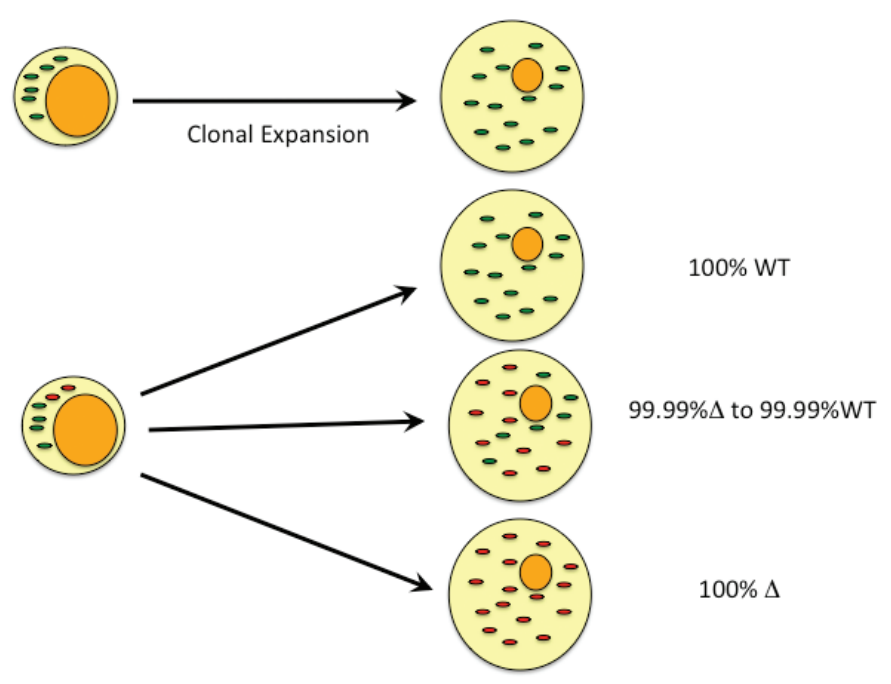

Fig. 5. mtDNA segregation during development. The mitochondrial genome is randomly segregated during early development. Consequently, the degree of heteroplasmy, where cells will possess mutant and WT mtDNA (natural fertilisation) or possess donor cell and recipient oocyte mtDNA (all forms of nuclear transfer), or homoplasmy can not be predicted in any particular tissue. Additionally, during development, one molecule may be preferentially selected for replication over another, potentially increasing nucleo-cytoplsmic dysfunction.

quence of these defects uncouples the ETC, altering energy production, production of ROS, modulation of calcium ion uptake and tendency to apoptosis. MtDNA is more susceptible to mutation than genomic DNA most likely due to the lack of histone packaging and the proximity to ROS (Nachman et al. 1996; Schriner et al. 2000; Wiesner et al. 2006). This is, however, contentious as TFAM is presumed to have a DNA packaging role also (Kaufman et al. 2007). Upon mutation of mtDNA, cells become heteroplasmic containing two types of mtDNA which are randomly segregated at mitosis, resulting in genetic drift towards mutated or wild type molecules. A threshold for cellular mutant loading exists which, once crossed, reduces energy output, disease phenotype prevails and the onset of necrosis or apoptosis is more likely. Interestingly, due to the random segregation to daughter cells, different phenotypes are observed for the same mutation (See Fig. 5; Wallace and Fan 2010). Variations of mitochondrial proteins can uncouple ATP production and influence the amount of calories used by the respiring mitochondria.

In humans, mitochondrial haplotypes are generally associated with specific populations and geographic regions, and permitted our ancestors to adapt to a range of new environments. Specific haplogroups predispose individuals to a wide range of metabolic and degenerative diseases as well as to cancer and longevity (Wallace et al. 2010; Wallace and Fan 2010). Cattle haplotypes can influence the ATP content of in vitro produced embryos (Bruggerhoff et al. 2002; Tamassia et al. 2004) and the compatibility of mtDNA haplotypes between donor cells and recipient cells in SCNT can influence developmental outcome and the epigenetic status of such embryos. Indeed, it has been hypothesised that the energetic state of a particular cell is communicated to the nucleus by modifications of nuclear chromatin via phosphorylation and acetylation mechanisms (Wallace et al. 2010; Wallace and Fan 2010).

\section{mtDNA copy number set point}

At fertilisation, the mitochondria present in mature oocytes are thought to be derived from a finite pool within PGCs (reviewed in Jansen and de Boer, 1998; Shoubridge and Wai, 2007). Random segregation within post-mitotic cells excludes predicting mitochondrial allele frequency in heteroplasmic individuals. The restoration of homoplasmy over a few generations in bovine (Hauswirth and Laipis 1982; Laipis et al. 1988; Ashley et al. 1989), human (Blok et al. 1997) and mouse (Meirelles and Smith 1997) progeny imply that during oogenesis a mtDNA bottleneck minimises heteroplasmic inheritance, maintaining homoplasmy perhaps due to a female germ line selection mechanism (Fan et al. 2008). PGCs are thought to contain approximately 10-200 copies of mtDNA and maintain relatively low numbers during the early stages of oogenesis (Smith and Alcivar 1993). During oogenesis, the expansion of the differentiating PGCs is accompanied by the clonal expansion of mtDNA (Chen et al., 1995; Poulton et al., 1998; Smith and Alcivar 1993). However, recent concordant studies have proposed alternative mechanisms for mtDNA segregation during PGC differentiation into a mature oocyte. It has been proposed that the mitochondrial bottleneck occurs without reduction of mtDNA content in mouse female germ cells (Cao et al. 2007; Cao et al. 2009) whilst others demonstrated mtDNA reduction during embryogenesis at 7.5 dpc in PGCs (Cree et al. 2008). In addition, Wai et al. (2008) concluded that the bottleneck is a result of replication of a subpopulation, not during embryogenesis but during postnatal oocyte maturation (Wai et al. 2008). Moreover, large levels of mtDNA replication have been shown to take place during the final stages of oocyte maturation (Jansen and de Boer, 1998; Spikings et al., 2007). These studies suggest further examination is required into the precise mechanism behind the bottleneck, although they highlight that the expansion of mtDNA copy number during oogenesis is an essential genetic mechanism.

Increased oxygen consumption, $\mathrm{CO}_{2}$ production and ATP output at the blastocyst stage occur in the differentiating trophectodermal cells (Houghton 2006; Spikings et al. 2007). Pluripotent embryonic stem cells derived from the inner cell mass (ICM) express numerous markers of pluripotency, such as Oct4 Sox2 and Nanog. Mouse ESCs (Facucho-Oliveira et al. 2007) and human ESCs (Cho et al. 2006; Prigione et al. 2010) contain low mtDNA copy numbers and structurally immature mitochondria (Kelly et al. submitted) compared to somatic cells. In addition, induced pluripotent stem cells (iPSC) display similar copy numbers and morphological characteristics to ESCs (Kelly et al. submitted). Therefore, it appears that the expression of pluripotent genes influences the levels of mtDNA copy number and mitochondrial function. Indeed, this association permits the developing embryo to establish the mtDNA 'set point' prior to gastrulation or cellular differentiation so that once a pathway of differentiation is initiated the progenitor cell may proliferate the mitochondrial complement in accordance with the precise cellular demands of its mature, adult form (See Fig. 6).

\section{Generating homoplasmic offspring and iSCNT embry- onic stem cells}

Prior to reconstruction, donor cells and/or recipient oocytes can be depleted of their mtDNA using various chemical reagents. 


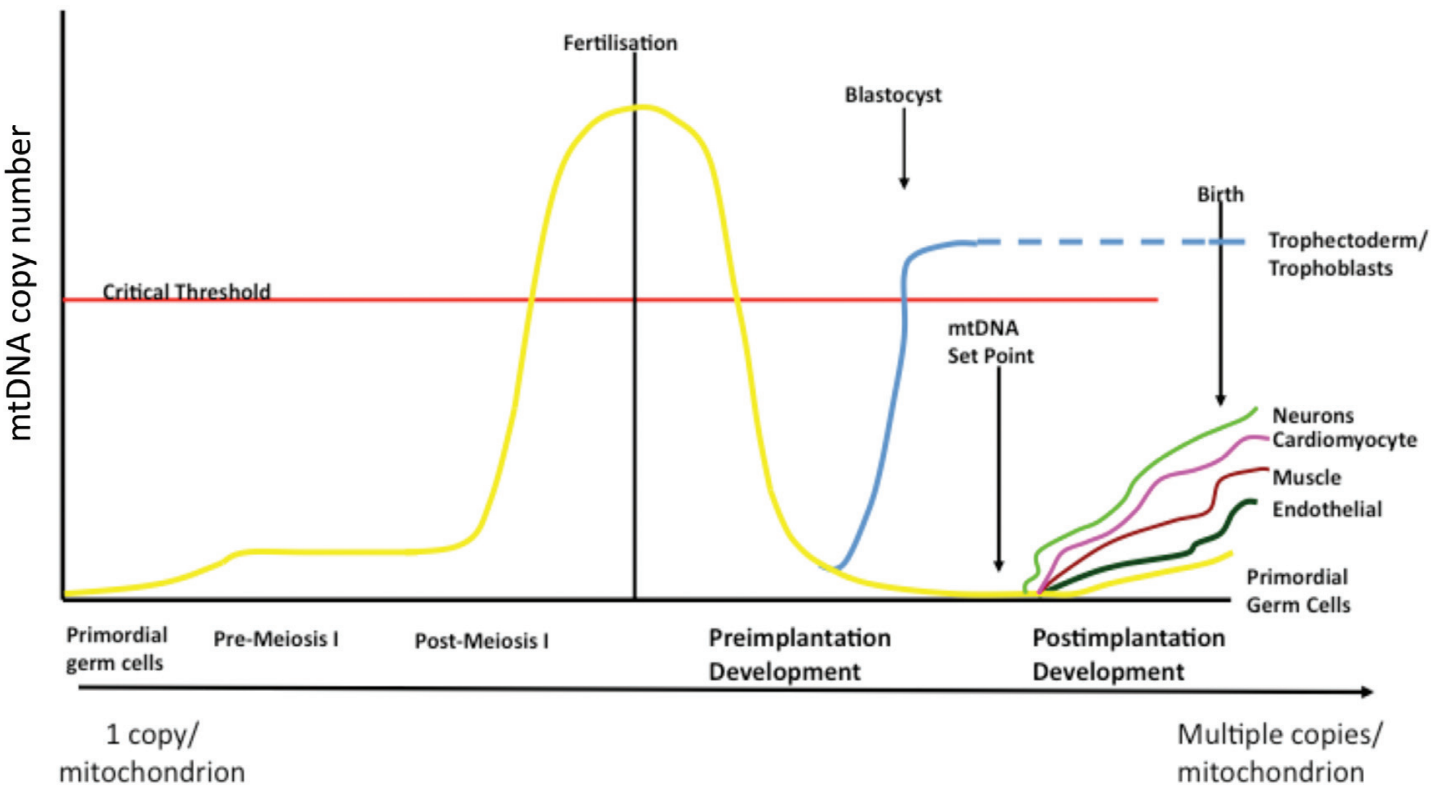

Fig. 6. mtDNA replication during development. MtDNA replication is strictly regulated during oogenesis, preimplantation development and pregastrulation. The mature oocyte possesses sufficient copies of mtDNA to meet its need for OXPHOS-derived ATP during fertilisation. MtDNA replication is then significantly reduced during preimplantation development with increases most likely taking place in the trophectoderm to aid implantation. The ICM cells continue to reduce copy number after each cell division thus establishing the 'mtDNA set point'. Undifferentiated and differentiating ESCs maintain very low copy number until they commit to specific lineages.

Donor cells containing all their mtDNA complement $\left(m t D N A^{+}\right)$and cells depleted to residual levels of mtDNA (mtDNA $\left.{ }^{\mathrm{B}}\right)$ both transmit their mtDNA to the blastocyst stage (Lloyd et al. 2006; Bowles et al. 2008). The advantage of depleting cells is, that following fusion of the somatic cell with the enucleated oocyte, the mtDNA replication factors, which are up-regulated, would be unable to replicate any persisting donor cell mtDNA thus ensuring transmission of mtDNA in a manner similar to natural fertilisation. Nevertheless, these depleted cells can support development to term and produce live lambs in which no donor somatic mtDNA is transmitted with the resultant offspring being homoplasmic for recipient oocyte $\mathrm{mtDNA}$-only whilst $\mathrm{mtDNA}^{+}$fetuses possessed donor cell mtDNA (Lee et al. 2010). Whilst SCNT protocols have concentrated on reprogramming and the effects of aberrant epigenetic regulation, it is important to note that homoplasmy, rather than heteroplasmy is a tightly regulated developmental process that ensures, in nearly all cases, the healthy status of the offspring is maintained. Not only is heteroplasmy with mutant mtDNA disadvantageous to the offspring but mixing of mtDNA haplotypes has similar outcomes (Barritt et al. 2001; Acton et al. 2007).

In iSCNT embryos donor cell mtDNA has been detected at the 16-cell stage in human-bovine crosses (Chang et al. 2003), the blastocysts stage in macaque-rabbit (Yang et al. 2003) and in a small majority of caprine-ovine embryos (Bowles et al. 2007b). In the small number of heteroplasmic embryos, significant increases in donor cell mtDNA were observed again indicating that donor mtDNA was preferentially replicated. The production of live interspecies offspring is extremely unlikely, however, for the generation of embryonic stem cells, nuclear cytoplasmic regulation is paramount for any clinical applications. Thus, the generation of iSCNT embryos and stem cells requires the elimination of recipient oocyte mtDNA as opposed to normal SCNT so that respiratory function, subsequent mitochondrial proliferation and differentiation are appropriate for cell function.

\section{References}

ALEXOPOULOS,N.I., MADDOX-HYTTEL,P., TVEDEN-NYBORG,P., D'CRUZ,N.T. TECIRLIOGLU,T.R., COONEY,M.A., SCHAUSER,K., HOLLAND,M.K. and FRENCH,A.J. (2008). Developmental disparity between in vitro-produced and somatic cell nuclear transfer bovine days 14 and 21 embryos: implications for embryonic loss. Reproduction 136: 433-445.

ANDERSON,S., BANKIER,A.T., BARRELL,B.G., DE BRUIJN,M.H. COULSON,A.R., DROUIN,J., EPERON,I.C., NIERLICH,D.P., ROE,B.A., SANGER,F., SCHREIER,P.H., SMITH,A.J., STADEN,R. and YOUNG,I.G. (1981). Sequence and organization of the human mitochondrial genome. Nature 290: 457-465.

ANDERSON,S., DE BRUIJN,M.H., COULSON,A.R., EPERON,I.C., SANGER,F. and YOUNG,I.G. (1982). Complete sequence of bovine mitochondrial DNA. Conserved features of the mammalian mitochondrial genome. J Mol Biol 156: 683-717.

ANDERSSON,S.G., KARLBERG,O., CANBACK,B. and KURLAND,C.G. (2003). On the origin of mitochondria: a genomics perspective. Philos Trans $R$ Soc Lond B Biol Sci 358: 165-177.

ASHLEY,M.V., LAIPIS,P.J. and HAUSWIRTH,W.W. (1989). Rapid segregation of heteroplasmic bovine mitochondria. Nucleic Acids Res 17: 7325-7331.

AU,H.K., YEH,T.S., KAO,S.H., TZENG,C.R. and HSIEH,R.H. (2005). Abnormal mitochondrial structure in human unfertilized oocytes and arrested embryos. Ann N Y Acad Sci 1042: 177-185.

BARNETT,D.K. and BAVISTER,B.D. (1996). What is the relationship between the metabolism of preimplantation embryos and their developmental competence? Mol Reprod Dev 43: 105-133.

BARRIENTOS,A., KENYON,L. and MORAES,C.T. (1998). Human xenomitochondrial cybrids. Cellular models of mitochondrial complex I deficiency. J Biol Chem 273, 14210-14217.

BAVISTER,B.D. and SQUIRRELL,J.M. (2000). Mitochondrial distribution and func- 
tion in oocytes and early embryos. Hum Reprod 15 (S2): 189-198.

BIBB,M.J., VANETTEN,R.A., WRIGHT,C.T., WALBERG,M.W. and CLAYTON,D.A. (1981). Sequence and gene organization of mouse mitochondrial DNA. Cell26: 167-180.

BIRKY,C.W., (1995). Uniparental inheritance of mitochondrial and chloroplast genes: mechanisms and evolution. Proc Natl Acad Sci USA 92: 11331-11338.

BIRKY,C.W., (2001). The inheritance of genes in mitochondria and chloroplasts: laws, mechanisms, and models. Annu Rev Genet: 35, 125-148.

BLOK,R.B., GOOK,D.A., THORBURN,D.R. and DAHL,H.H. (1997). Skewed segregation of the mtDNA nt $8993(T->G)$ mutation in human oocytes. Am J Hum Genet 60: 1495-1501.

BOSE,H.S., LINGAPPA,V.R. and MILLER,W.L. (2002). Rapid regulation of steroidogenesis by mitochondrial protein import. Nature 417: 87-91.

BOWLES,E.J., CAMPBELL,K.H. and ST JOHN,J.C. (2007). Nuclear transfer: preservation of a nuclear genome at the expense of its associated mtDNA genome(s). Curr Top Dev Biol: 77: 251-290.

BOWLES,E.J., LEE,J.H., ALBERIO,R., LLOYD,R.E., STEKEL,D., CAMPBELL,K.H. and ST JOHN,J.C. (2007). Contrasting effects of in vitro fertilization and nuclear transfer on the expression of mtDNA replication factors. Genetics 176: 1511 1526

BOWLES,E.J., TECIRLIOGLU,R.T., FRENCH,A.J., HOLLAND,M.K. and ST JOHN,J.C. (2008). Mitochondrial DNA transmission and transcription after somatic cell fusion to one or more cytoplasts. Stem Cells 26: 775-782.

BRENNER,C.A., BARRITT,J.A., WILLADSEN,S. and COHEN,J. (2000). Mitochondrial DNA heteroplasmy after human ooplasmic transplantation. Fertil Steril 74: 573-578.

BRINI,M. (2003). Ca(2+) signalling in mitochondria: mechanism and role in physiology and pathology. Cell Calcium 34: 399-405.

BRISON,D.R., HEWITSON,L.C. and LEESE,H.J. (1993). Glucose, pyruvate, and lactate concentrations in the blastocoel cavity of rat and mouse embryos. $\mathrm{Mol}$ Reprod Dev 35: 227-232.

BRISON,D.R. and LEESE,H.J. (1991). Energy metabolism in late preimplantation rat embryos. J. Reprod Fertil 93: 245-251.

BROWN,G.C. (1992). Control of respiration and ATP synthesis in mammalian mitochondria and cells. Biochem J 284: (Pt 1), 1-13.

BRUGGERHOFF,K., ZAKHARTCHENKO,V., WENIGERKIND,H., REICHENBACH,H.D., PRELLE,K., SCHERNTHANER,W., ALBERIO,R., KUCHENHOFF,H., STOJKOVIC,M., BREM,G., HIENDLEDER,S. and WOLF,E. (2002). Bovine somatic cell nuclear transfer using recipient oocytes recovered by ovum pick-up: effect of maternal lineage of oocyte donors. Biol Reprod 66: 367-373.

BURGSTALLER,J.P., SCHINOGL,P., DINNYES,A., MULLER,M. and STEINBORN,R. (2007). Mitochondrial DNA heteroplasmy in ovine fetuses and sheep cloned by somatic cell nuclear transfer. BMC Dev Biol 7: 141.

CAMPBELL,K.H., FISHER,P., CHEN,W.C., CHOI,I., KELLY,R.D., LEE,J.H. and $\mathrm{XHU,J.} \mathrm{(2007).} \mathrm{Somatic} \mathrm{cell} \mathrm{nuclear} \mathrm{transfer:} \mathrm{Past,} \mathrm{present} \mathrm{and} \mathrm{future} \mathrm{perspec-}$ tives. Theriogenology 68 (S1): S214-S231.

CAO,L., SHITARA,H., HORII,T., NAGAO,Y., IMAI,H., ABE,K., HARA,T., HAYASHI,J. and YONEKAWA, H. (2007) The mitochondrial bottleneck occurs without reduction of mtDNA content in female mouse germ cells. Nat Genet 39: 386-390.

CAO,L., SHITARA,H., SUGIMOTO,M., HAYASHI,J., ABE,K. and YONEKAWA,H. (2009). New evidence confirms that the mitochondrial bottleneck is generated without reduction of mitochondrial DNA content in early primordial germ cells of mice. PLoS Genet 5: e1000756.

CHANG,K.H., LIM,J.M., KANG,S.K., LEE,B.C., MOON,S.Y. and HWANG,W.S. (2003). Blastocyst formation, karyotype, and mitochondrial DNA of interspecies embryos derived from nuclear transfer of human cord fibroblasts into enucleated bovine oocytes. Fertil Steril 80: 1380-1387.

CHO,Y.M., KWON,S., PAK,Y.K., SEOL,H.W., CHOI,Y.M., PARK,d.J., PARK,K.S. and LEE,H.K. (2006). Dynamic changes in mitochondrial biogenesis and antioxidant enzymes during the spontaneous differentiation of human embryonic stem cells. Biochem Biophys Res Commun 348: 1472-1478.

CHUNG,Y.G., MANN,M.R., BARTOLOMEI,M.S. and LATHAM,K.E. (2002). Nuclearcytoplasmic «tug of war» during cloning: effects of somatic cell nuclei on culture medium preferences of preimplantation cloned mouse embryos. Biol Reprod 66: 1178-1184.
COPELAND,W.C. (2008). Inherited mitochondrial diseases of DNA replication Annu Rev Med 59: 131-146.

CRAVEN,L., TUPPEN,H.A., GREGGAINS,G.D., HARBOTTLE,S.J., MURPHY,J.L., CREE,L.M., MURDOCH,A.P., CHINNERY,P.F., TAYLOR,R.W., LIGHTOWLERS,R.N., HERBERT,M. and TURNBULL,D.M. (2010). Pronuclear transfer in human embryos to prevent transmission of mitochondrial DNA disease. Nature 465: 82-85.

CREE,L.M., SAMUELS,D.C., DE SOUSA LOPES,S.C., RAJASIMHA,H.K., WONNAPINIJ,P., MANN,J.R., DAHL,H.H. and CHINNERY,P.F. (2008). A reduction of mitochondrial DNA molecules during embryogenesis explains the rapid segregation of genotypes. Nat Genet 40: 249-254.

CROSIER,A.E., FARIN,P.W., DYKSTRA,M.J., ALEXANDER,J.E. and FARIN,C.E. (2000). Ultrastructural morphometry of bovine compact morulae produced in vivo or in vitro. Biol Reprod 62: 1459-1465

CROSIER,A.E., FARIN,P.W., DYKSTRA,M.J., ALEXANDER,J.E. and FARIN,C.E. (2001). Ultrastructural morphometry of bovine blastocysts produced in vivo or in vitro. Biol Reprod 64: 1375-1385.

DEDKOVA,E.N., JI,X., LIPSIUS,S.L. and BLATTER,L.A. (2004). Mitochondrial calcium uptake stimulates nitric oxide production in mitochondria of bovine vascular endothelial cells. Am J Physiol Cell Physioln286: C406-C415.

DIMAURO,S. and SCHON,E.A. (2001). Mitochondrial DNA mutations in human disease. Am J Med Genet 106: 18-26.

DIMAURO,S. and SCHON,E.A. (2008). Mitochondrial disorders in the nervous system. Annu Rev Neurosci 31: 91-123.

DO,J.T., LEE,J.W., LEE,B.Y., KIM,S.B., RYOO,Z.Y., LEE,H.T. and CHUNG,K.S (2002). Fate of donor mitochondrial DNA in cloned bovine embryos produced by microinjection of cumulus cells. Biol Reprod 67: 555-560.

DUMOLLARD,R., DUCHEN,M. and SARDET,C. (2006). Calcium signals and mitochondria at fertilisation. Semin Cell Dev Biol 17: 314-323.

EL SHOURBAGY,S.H., SPIKINGS,E.C., FREITAS,M. and ST JOHN,J.C. (2006). Mitochondria directly influence fertilisation outcome in the pig. Reproduction 131: 233-245.

ERECINSKA,M. and SILVER,I.A. (1989). ATP and brain function. J Cereb Blood Flow Metab 9: 2-19.

EVANS,M.J., GURER,C., LOIKE,J.D., WILMUT,I., SCHNIEKE,A.E. and SCHON,E.A. (1999). Mitochondrial DNA genotypes in nuclear transfer-derived cloned sheep. Nat Genet 23: 90-93.

FACUCHO-OLIVEIRA,J.M., ALDERSON,J., SPIKINGS,E.C., EGGINTON,S. and ST JOHN,J.C. (2007). Mitochondrial DNA replication during differentiation of murine embryonic stem cells. J Cell Sci 120: 4025-4034.

FALKENBERG,M., LARSSON,N.G. and GUSTAFSSON,C.M. (2007). DNA replication and transcription in mammalian mitochondria. Annu Rev Biochem 76 : 679-699.

FAN,W., WAYMIRE,K.G., NARULA,N., LI,P., ROCHER,C., COSKUN,P.E. VANNAN,M.A., NARULA,J., MACGREGOR,G.R. and WALLACE,D.C. (2008). $A$ mouse model of mitochondrial disease reveals germline selection against severe mtDNA mutations. Science 319: 958-962.

FISHER,R.P. and CLAYTON,D.A. (1985). A transcription factor required for promoter recognition by human mitochondrial RNA polymerase. Accurate initiation at the heavy- and light-strand promoters dissected and reconstituted in vitro. $J$ Biol Chem 260: 11330-11338.

GAO,S., CHUNG,Y.G., WILLIAMS,J.W., RILEY,J., MOLEY,K. and LATHAM,K.E. (2003). Somatic cell-like features of cloned mouse embryos prepared with cultured myoblast nuclei. Biol Reprod 69: 48-56.

GJORRET,J.O., FABIAN,D., AVERY,B. and MADDOX-HYTTEL,P. (2007). Active caspase-3 and ultrastructural evidence of apoptosis in spontaneous and induced cell death in bovine in vitro produced pre-implantation embryos. $\mathrm{Mo}$ Reprod Dev 74: 961-971.

GOTT,A.L., HARDY,K., WINSTON,R.M. and LEESE,H.J. (1990). Non-invasive measurement of pyruvate and glucose uptake and lactate production by single human preimplantation embryos. Hum Reprod 5: 104-108.

GRAY,M.W., BURGER,G. and LANG,B.F. (1999). Mitochondrial evolution. Science 283: 1476-1481

GYLLENSTEN,U., WHARTON,D., JOSEFSSON,A. and WILSON,A.C. (1991) Paternal inheritance of mitochondrial DNA in mice. Nature 352: 255-257. 
HAN,Z., VASSENA,R., CHI,M.M., POTIREDDY,S., SUTOVSKY,M., MOLEY,K.H., SUTOVSKY,P. and LATHAM,K.E. (2008). Role of glucose in cloned mouse embryo development. Am J Physiol Endocrinol Metab 295: E798-E809.

HAO,Y., LAI,L., MAO,J., IM,G.S., BONK,A. and PRATHER,R.S. (2003). Apoptosis and in vitro development of preimplantation porcine embryos derived in vitro or by nuclear transfer. Biol Reprod 69: 501-507.

HAO,Y., LAI,L., MAO,J., IM,G.S., BONK,A. and PRATHER,R.S. (2004). Apoptosis in parthenogenetic preimplantation porcine embryos. Biol Reprod 70: 16441649.

HARDY,K. (1999). Apoptosis in the human embryo. Rev. Reprod. 4: 125-134.

HAUSWIRTH,W.W. and LAIPIS,P.J. (1982). Mitochondrial DNA polymorphism in a maternal lineage of Holstein cows. Proc Natl Acad Sci USA 79: 4686-4690.

HEINDRYCKX,B., RYBOUCHKIN,A., VAN DER,E.J. and DHONT,M. (2001). Effect of culture media on in vitro development of cloned mouse embryos. Cloning 3 : 41-50.

HEINEMAN,F.W. and BALABAN,R.S. (1990). Control of mitochondrial respiration in the heart in vivo. Annu Rev Physiol 52: 523-542.

HIENDLEDER,S., SCHMUTZ,S.M., ERHARDT,G., GREEN,R.D. and PLANTE,Y. (1999). Transmitochondrial differences and varying levels of heteroplasmy in nuclear transfer cloned cattle. Mol Reprod Dev 54: 24-31.

HIENDLEDER,S., ZAKHARTCHENKO,V., WENIGERKIND, H., REICHENBACH,H.D., BRUGGERHOFF,K., PRELLE,K., BREM,G., STOJKOVIC,M. and WOLF,E. (2003). Heteroplasmy in bovine fetuses produced by intra- and inter-subspecific somatic cell nuclear transfer: neutral segregation of nuclear donor mitochondrial DNA in various tissues and evidence for recipient cow mitochondria in fetal blood. Biol Reprod 68: 159-166.

HILLMAN,N. and HILLMAN,R. (1975). Ultrastructural studies of tw32/tw32 mouse embryos. J. Embryol Exp Morphol 33: 685-695.

HILLMAN,N. and TASCA,R.J. (1969). Ultrastructural and autoradiographic studies of mouse cleavage stages. Am J Anat 126: 151-173.

HOUGHTON,F.D. (2006). Energy metabolism of the inner cell mass and trophectoderm of the mouse blastocyst. Differentiation 74: 11-18.

HOUGHTON,F.D., THOMPSON,J.G., KENNEDY,C.J. and LEESE,H.J. (1996). Oxygen consumption and energy metabolism of the early mouse embryo. Mol Reprod Dev 44: 476-485.

HUA,S., ZHANG,Y., LI,X.C., MA,L.B., CAO,J.W., DAI,J.P. and LI,R. (2007). Effects of granulosa cell mitochondria transfer on the early development of bovine embryos in vitro. Cloning Stem Cells 9: 237-246.

HUA,S., ZHANG, Y., SONG,K., SONG,J., ZHANG,Z., ZHANG,L., ZHANG,C., CAO,J. and MA,L. (2008). Development of bovine-ovine interspecies cloned embryos and mitochondria segregation in blastomeres during preimplantation. Anim Reprod Sci 105: 245-257.

JANSEN,R.P. and DE BOER, B.K. (1998). The bottleneck: mitochondrial imperatives in oogenesis and ovarian follicular fate. Mol Cell Endocrinol 145: 81-88.

JOZA,N., SUSIN,S.A., DAUGAS,E., STANFORD,W.L., CHO,S.K., LI,C.Y., SASAKI,T., ELIA,A.J., CHENG,H.Y., RAVAGNAN,L., FERRI,K.F., ZAMZAMI,N., WAKEHAM,A., HAKEM,R., YOSHIDA,H., KONG,Y.Y., MAK,T.W., ZUNIGAPFLUCKER,J.C., KROEMER,G. and PENNINGER,J.M. (2001). Essential role of the mitochondrial apoptosis-inducing factor in programmed cell death. Nature 410: 549-554.

KAMJOO,M., BRISON,D.R. and KIMBER,S.J. (2002). Apoptosis in the preimplantation mouse embryo: effect of strain difference and in vitro culture. Mol Reprod Dev 61: 67-77.

KATAYAMA,M., ZHONG,Z., LAI,L., SUTOVSKY,P., PRATHER,R.S. and SCHATTEN,H. (2006). Mitochondrial distribution and microtubule organization in fertilized and cloned porcine embryos: implications for developmental potential. Dev Biol 299: 206-220.

KAUFMAN,B.A., DURISIC,N., MATIVETSKY,J.M., COSTANTINO,S., HANCOCK,M.A., GRUTTER,P. and SHOUBRIDGE,E.A. (2007). The mitochondrial transcription factor TFAM coordinates the assembly of multiple DNA molecules into nucleoid-like structures. Mol Biol Cell 18: 3225-3236.

KENYON,L. and MORAES,C.T. (1997). Expanding the functional human mitochondrial DNA database by the establishment of primate xenomitochondrial cybrids. Proc Natl Acad Sci USA 94: 9131-9135.

KING,W.A., SHEPHERD,D.L., PLANTE,L., LAVOIR,M.C., LOONEY,C.R. and BARNES,F.L. (1996). Nucleolar and mitochondrial morphology in bovine em- bryos reconstructed by nuclear transfer. Mol Reprod Dev 44: 499-506.

KORHONEN,J.A., GASPARI,M. and FALKENBERG,M. (2003). TWINKLE Has $5{ }^{\prime}$ $>3$ ' DNA helicase activity and is specifically stimulated by mitochondrial singlestranded DNA-binding protein. J Biol Chem 278: 48627-48632.

LAIPIS,P.J., VAN DE WALLE,M.J. and HAUSWIRTH,W.W. (1988). Unequal partitioning of bovine mitochondrial genotypes among siblings. Proc Natl Acad Sci USA 85: 8107-8110.

LANG,B.F., GRAY,M.W. and BURGER,G. (1999). Mitochondrial genome evolution and the origin of eukaryotes. Annu Rev Genet 33: 351-397.

LANSMAN,R.A., AVISE,J.C. and HUETTEL,M.D. (1983). Critical experimental test of the possibility of «paternal leakage» of mitochondrial DNA. Proc Natl Acad Sc USA 80: 1969-1971.

LARSSON,N.G., WANG,J., WILHELMSSON,H., OLDFORS,A., RUSTIN,P., LEWANDOSKI,M., BARSH,G.S. and CLAYTON,D.A. (1998). Mitochondria transcription factor $A$ is necessary for mtDNA maintenance and embryogenesis in mice. Nat Genet 18: 231-236.

LEE, JH., PETERS, A., FISHER, P., BOWLES, EJ., ST JOHN, JC., AND CAMPBELL, KHS., (2010). Generation of mtDNA Homoplasmic Cloned Lambs. Cellular Reprogramming 12: 347- 355

LEESE,H.J., CONAGHAN,J., MARTIN,K.L. and HARDY,K. (1993). Early human embryo metabolism. Bioessays 15: 259-264.

LEESE,H.J. and LENTON,E.A. (1990). Glucose and lactate in human follicular fluid: concentrations and interrelationships. Hum Reprod 5: 915-919.

LLOYD,R.E., LEE,J.H., ALBERIO,R., BOWLES,E.J., RAMALHO-SANTOS,J., CAMPBELL,K.H. and ST JOHN,J.C. (2006). Aberrant nucleo-cytoplasmic crosstalk results in donor cell mtDNA persistence in cloned embryos. Genetics 172 2515-2527.

LOI,P., PTAK,G., BARBONI,B., FULKA,J., Jr., CAPPAI,P. and CLINTON,M. (2001). Genetic rescue of an endangered mammal by cross-species nuclear transfer using post-mortem somatic cells. Nat Biotechnol 19: 962-964.

LOI,P., PTAK,G., DATTENA,M., LEDDA,S., NAITANA,S. and CAPPAI,P. (1998). Embryo transfer and related technologies in sheep reproduction. Reprod Nutr Dev 38: 615-628.

MA,L.B., YANG,L., HUA,S., CAO,J.W., LI,J.X. and ZHANG,Y. (2008). Development in vitro and mitochondrial fate of interspecies cloned embryos. Reprod Domest Anim 43: 279-285.

MADDOX-HYTTELL,P., GJORRET,J.O., VAJTA,G., ALEXOPOULOS,N.I., LEWIS,I., TROUNSON,A., VIUFF,D., LAURINCIK,J., MULLER,M., TVEDENNYBORG,P. and THOMSEN,P.D. (2003). Morphological assessment of preimplantation embryo quality in cattle. Reprod Supp/ 61: 103-116.

MATWEE,C., BETTS,D.H. and KING,W.A. (2000). Apoptosis in the early bovine embryo. Zygote 8: 57-68.

MAY-PANLOUP,P., CHRETIEN,M.F., JACQUES,C., VASSEUR,C., MALTHIERY,Y and REYNIER,P. (2005). Low oocyte mitochondrial DNA content in ovarian insufficiency. Hum Reprod 20: 593-597.

MAY-PANLOUP,P., VIGNON,X., CHRETIEN,M.F., HEYMAN,Y., TAMASSIA,M. MALTHIERY,Y. and REYNIER,P. (2005). Increase of mitochondrial DNA content and transcripts in early bovine embryogenesis associated with upregulation of mtTFA and NRF1 transcription factors. Reprod Biol Endocrinol 3: 65

MCCONNELL,J.M. and PETRIE,L. (2004). Mitochondrial DNA turnover occurs during preimplantation development and can be modulated by environmental factors. Reprod Biomed Online 9: 418-424.

MEIRELLES,F.V., BORDIGNON,V., WATANABE,Y., WATANABE,M., DAYAN,A LOBO,R.B., GARCIA,J.M. and SMITH,L.C. (2001). Complete replacement of the mitochondrial genotype in a Bos indicus calf reconstructed by nuclear transfer to a Bos taurus oocyte. Genetics 158: 351-356.

MEIRELLES,F.V. and SMITH,L.C. (1997). Mitochondrial genotype segregation in a mouse heteroplasmic lineage produced by embryonic karyoplast transplantation. Genetics 145: 445-451.

MICHAELS,G.S., HAUSWIRTH,W.W. and LAIPIS,P.J. (1982). Mitochondrial DNA copy number in bovine oocytes and somatic cells. Dev Biol 94: 246-251.

MILLER,F.J., ROSENFELDT,F.L., ZHANG,C., LINNANE,A.W. and NAGLEY,P (2003). Precise determination of mitochondrial DNA copy number in human skeletal and cardiac muscle by a PCR-based assay: lack of change of copy number with age. Nucleic Acids Res 31: e61.

MOTTA,P.M., NOTTOLA,S.A., MAKABE,S. and HEYN,R. (2000). Mitochondrial 
morphology in human fetal and adult female germ cells. Hum Reprod 15: 129147.

MOYES,C.D. (2003). Controlling muscle mitochondrial content. J Exp Biol 206: 4385-4391.

MOYES,C.D., BATTERSBY,B.J. and LEARY,S.C. (1998). Regulation of muscle mitochondrial design. J Exp Biol 201: 299-307.

NACHMAN,M.W., BROWN,W.M., STONEKING,M. and AQUADRO,C.F. (1996) Nonneutral mitochondrial DNA variation in humans and chimpanzees. Genetics 142: 953-963.

NEMOTO,S., TAKEDA,K., YU,Z.X., FERRANS,V.J. and FINKEL,T. (2000). Role for mitochondrial oxidants as regulators of cellular metabolism. $\mathrm{Mol} \mathrm{Cell} \mathrm{Biol20:}$ 7311-7318.

NISOLI,E., CLEMENTI,E., MONCADA,S. and CARRUBA,M.O. (2004). Mitochondrial biogenesis as a cellular signaling framework. Biochem Pharmacol 67: 115.

PFEIFFER,T., SCHUSTER,S. and BONHOEFFER,S. (2001). Cooperation and competition in the evolution of ATP-producing pathways. Science 292: 504-507.

PIKO,L. and TAYLOR,K.D. (1987). Amounts of mitochondrial DNA and abundance of some mitochondrial gene transcripts in early mouse embryos. Dev Biol 123: 364-374.

PLANTE,L. and KING,W.A. (1994). Light and electron microscopic analysis of bovine embryos derived by in vitro and in vivo fertilization. $J$ Assist Reprod Genet 11: 515-529.

PRIGIONE,A., FAULER,B., LURZ,R., LEHRACH,H. and ADJAYE,J. (2010). The senescence-related mitochondrial/oxidative stress pathway is repressed in human induced pluripotent stem cells. Stem Cells 28: 721-733.

RAMALHO-SANTOS,J., VARUM,S., AMARAL,S., MOTA,P.C., SOUSA,A.P. and AMARAL,A. (2009). Mitochondrial functionality in reproduction: from gonads and gametes to embryos and embryonic stem cells. Hum Reprod Update 15: 553-572.

REYNIER,P., MAY-PANLOUP,P., CHRETIEN,M.F., MORGAN,C.J., JEAN,M., SAVAGNER,F., BARRIERE,P. and MALTHIERY,Y. (2001). Mitochondrial DNA content affects the fertilizability of human oocytes. Mol Hum Reprod 7: 425-429.

RODRIGUEZ-GONZALEZ,E., LOPEZ-BEJAR,M., VELILLA,E. and PARAMIO,M.T. (2002). Selection of prepubertal goat oocytes using the brilliant cresyl blue test. Theriogenology 57: 1397-1409.

SANTOS,T.A., EL,S.S. and ST JOHN,J.C. (2006). Mitochondrial content reflects oocyte variability and fertilization outcome. Fertil Steril 85: 584-591.

SATOH,M. and KUROIWA,T. (1991). Organization of multiple nucleoids and DNA molecules in mitochondria of a human cell. Exp Cell Res 196: 137-140.

SCHAEFER,A.M., MCFARLAND,R., BLAKELY,E.L., HE,L., WHITTAKER,R.G., TAYLOR,R.W., CHINNERY,P.F. and TURNBULL,D.M. (2008). Prevalence of mitochondrial DNA disease in adults. Ann Neurol 63: 35-39.

SCHAEFER,A.M., TAYLOR,R.W., TURNBULL,D.M. and CHINNERY,P.F. (2004). The epidemiology of mitochondrial disorders-past, present and future. Biochim Biophys Acta 1659: 115-120.

SCHRINER,S.E., OGBURN,C.E., SMITH,A.C., NEWCOMB,T.G., LADIGES,W.C., DOLLE,M.E., VIJG,J., FUKUCHI,K. and MARTIN,G.M. (2000). Levels of DNA damage are unaltered in mice overexpressing human catalase in nuclei. Free Radic Biol Med 29 664-673.

SCHWARTZ,M. and VISSING,J. (2002). Paternal inheritance of mitochondrial DNA. N Engl J Med 347: 576-580.

SHADEL,G.S. and CLAYTON,D.A. (1997). Mitochondrial DNA maintenance in vertebrates. Annu Rev Biochem 66: 409-435.

SHADEL,G.S. and CLAYTON,D.A. (1996). Mapping promoters in displacementloop region of vertebrate mitochondrial DNA. Methods Enzymol 264: 139-148.

SHOUBRIDGE,E.A. (2000). Mitochondrial DNA segregation in the developing embryo. Hum Reprod 15: (S2), 229-234.

SHOUBRIDGE,E.A. and WAI,T. (2007). Mitochondrial DNA and the mammalian oocyte. Curr Top Dev Biol 77: 87-111.

SMITH,L.C. and ALCIVAR,A.A. (1993). Cytoplasmic inheritance and its effects on development and performance. J Reprod Fertil Suppl 48: 31-43.

SPIKINGS,E.C., ALDERSON,J. and ST JOHN,J.C. (2007). Regulated mitochondrial DNA replication during oocyte maturation is essential for successful porcine embryonic development. Biol Reprod 76: 327-335.
SQUIRRELL,J.M., SCHRAMM,R.D., PAPROCKI,A.M., WOKOSIN,D.L. and BAVISTER,B.D. (2003). Imaging mitochondrial organization in living primate oocytes and embryos using multiphoton microscopy. Microsc Microanal9: 190201.

ST JOHN,J.C. (2002). The transmission of mitochondrial DNA following assisted reproductive techniques. Theriogenology 57: 109-123.

ST JOHN,J.C., ARMSTRONG,L., MINGER,S.L. and CAMPBELL,K.H. (2008). Law should recognize value of interspecies embryos. Nature 451: 627.

ST JOHN,J.C. and BARRATT,C.L. (1997). Use of anucleate donor oocyte cytoplasm in recipient eggs. Lancet 350: 961-962.

ST JOHN,J.C. and CAMPBELL,K.H. (2010). The battle to prevent the transmission of mitochondrial DNA disease: Is karyoplast transfer the answer? Gene Ther 17:147-9.

ST JOHN,J.C., MOFFATT,O. and D'SOUZA,N. (2005). Aberrant heteroplasmic transmission of mtDNA in cloned pigs arising from double nuclear transfer. $\mathrm{Mol}$ Reprod Dev 72: 450-460.

ST. JOHN,J. and LOVELL-BADGE,R. (2007). Human-animal cytoplasmic hybrid embryos, mitochondria, and an energetic debate. Nat Cell Biol 9: 988-992.

ST. JOHN,J. (2002). Ooplasm donation in humans: the need to investigate the transmission of mitochondrial DNA following cytoplasmic transfer. Hum Reprod 17: 1954-1958.

ST. JOHN,J., and SCHATTEN,G. (2004). Paternal mitochondrial DNA transmission during nonhuman primate nuclear transfer. Genetics 167: 897-905.

STEINBORN,R., SCHINOGL,P., WELLS,D.N., BERGTHALER,A., MULLER,M. and BREM,G. (2002). Coexistence of Bos taurus and B. indicus mitochondria DNAs in nuclear transfer-derived somatic cattle clones. Genetics 162: 823-829.

STEINBORN,R., ZAKHARTCHENKO,V., JELYAZKOV,J., KLEIN,D., WOLF,E., MULLER,M. and BREM,G. (1998). Composition of parental mitochondrial DNA in cloned bovine embryos. FEBS Lett 426: 352-356.

STURMEY,R.G. and LEESE,H.J. (2003). Energy metabolism in pig oocytes and early embryos. Reproduction 126: 197-204.

SUTOVSKY,P., MORENO,R.D., RAMALHO-SANTOS,J., DOMINKO,T., SIMERLY,C. and SCHATTEN,G. (1999). Ubiquitin tag for sperm mitochondria. Nature 402: 371-372.

SUTOVSKY,P., MORENO,R.D., RAMALHO-SANTOS,J., DOMINKO,T SIMERLY,C. and SCHATTEN,G. (2000). Ubiquitinated sperm mitochondria, selective proteolysis, and the regulation of mitochondrial inheritance in mammalian embryos. Biol Reprod 63: 582-590.

TAKEDA,K., AKAGI,S., KANEYAMA,K., KOJIMA,T., TAKAHASHI,S., IMAI,H., YAMANAKA,M., ONISHI,A. and HANADA,H. (2003). Proliferation of donor mitochondrial DNA in nuclear transfer calves (Bos taurus). derived from cumulus cells. Mol Reprod Dev 64: 429-437.

TAKEDA,K., TAKAHASHI,S., ONISHI,A., GOTO,Y., MIYAZAWA,A. and IMAI,H. (1999). Dominant distribution of mitochondrial DNA from recipient oocytes in bovine embryos and offspring after nuclear transfer. J Reprod Fertil 116: 253259.

TAKEDA,K., TASAI,M., IWAMOTO,M., ONISHI,A., TAGAMI,T., NIRASAWA,K., HANADA,H. and PINKERT,C.A. (2005). Microinjection of cytoplasm or mitochondria derived from somatic cells affects parthenogenetic development of murine oocytes. Biol Reprod 72: 1397-1404.

TAMASSIA,M., NUTTINCK,F., MAY-PANLOUP,P., REYNIER,P., HEYMAN,Y., CHARPIGNY,G., STOJKOVIC,M., HIENDLEDER,S., RENARD,J.P. and CHASTANT-MAILLARD,S. (2004). In vitro embryo production efficiency in cattle and its association with oocyte adenosine triphosphate content, quantity of mitochondrial DNA, and mitochondrial DNA haplogroup. Biol Reprod71: 697704.

TAO,Y., CHENG,L., ZHANG,M., LI,B., DING,J., ZHANG,Y., FANG,F., ZHANG,X and MADDOX-HYTTEL,P. (2008). Ultrastructural changes in goat interspecies and intraspecies reconstructed early embryos. Zygote 16: 93-110.

THOMPSON,J.G., BELL,A.C., PUGH,P.A. and TERVIT,H.R. (1993). Metabolism of pyruvate by pre-elongation sheep embryos and effect of pyruvate and lactate concentrations during culture in vitro. Reprod Fertil Dev 5: 417-423.

THOMPSON,J.G., MCNAUGHTON,C., GASPARRINI,B., MCGOWAN,L.T. and TERVIT,H.R. (2000). Effect of inhibitors and uncouplers of oxidative phosphorylation during compaction and blastulation of bovine embryos cultured in vitro. J Reprod Fertil 118: 47-55. 
THOMPSON,J.G., PARTRIDGE,R.J., HOUGHTON,F.D., COX,C.I. and LEESE,H.J. (1996). Oxygen uptake and carbohydrate metabolism by in vitro derived bovine embryos. J Reprod Fertil 106: 299-306.

THOMPSON,J.G., SIMPSON,A.C., PUGH,P.A. and TERVIT,H.R. (1992). Requirement for glucose during in vitro culture of sheep preimplantation embryos. $\mathrm{Mol}$ Reprod Dev 31: 253-257.

THOMPSON,J.G., SIMPSON,A.C., PUGH,P.A., WRIGHT,R.W., Jr. and TERVIT,H.R. (1991). Glucose utilization by sheep embryos derived in vivo and in vitro. Reprod Fertil Dev 3: 571-576.

THUNDATHIL,J., FILION,F. and SMITH,L.C. (2005). Molecular control of mitochondrial function in preimplantation mouse embryos. Mol Reprod Dev 71: 405413.

TIAN,W.N., BRAUNSTEIN,L.D., PANG,J., STUHLMEIER,K.M., XI,Q.C., TIAN,X and STANTON,R.C. (1998). Importance of glucose-6-phosphate dehydrogenase activity for cell growth. J Biol Chem 273: 10609-10617.

URSING,B.M. and ARNASON,U. (1998). The complete mitochondrial DNA sequence of the pig (Sus scrofa). J Mol Evol 47: 302-306.

VAN,B.J. (2000). Intrafollicular influences on human oocyte developmental competence: perifollicular vascularity, oocyte metabolism and mitochondrial function. Hum Reprod 15: (S2), 173-188.

VAN,B.J., BELL,H. and WEIPZ,D. (1990). Cellular and developmental biological aspects of bovine meiotic maturation, fertilization, and preimplantation embryogenesis in vitro. J Electron Microsc Tech 16: 298-323.

VAN,B.J., DAVIS,P. and ALEXANDER,S. (2000). Differential mitochondrial distribution in human pronuclear embryos leads to disproportionate inheritance between blastomeres: relationship to microtubular organization, ATP content and competence. Hum Reprod 15: 2621-2633.

WAI,T., AO,A., ZHANG,X., CYR,D., DUFORT,D. and SHOUBRIDGE,E.A. (2010). The Role of Mitochondrial DNA Copy Number in Mammalian Fertility. Biol Reprod 83(1): 52-62

WAI,T., TEOLI,D. and SHOUBRIDGE,E.A. (2008). The mitochondrial DNA genetic bottleneck results from replication of a subpopulation of genomes. Nat Genet 40; 1484-1488.

WALLACE,D.C. (1999). Mitochondrial diseases in man and mouse. Science 283: 1482-1488.

WALLACE,D.C. (2005). The mitochondrial genome in human adaptive radiation and disease: on the road to therapeutics and performance enhancement. Gene 354: 169-180.

WALLACE,D.C. and FAN,W. (2010). Energetics, epigenetics, mitochondrial genetics. Mitochondrion 10; 12-31.
WALLACE,D.C., FAN,W. and PROCACCIO,V. (2010). Mitochondrial energetics and therapeutics. Annu Rev Pathol 5; 297-348.

WALLACE,D.C. and MURDOCK,D.G. (1999). Mitochondria and dystonia: the movement disorder connection? Proc Natl Acad Sci USA 96; 1817-1819.

WASSARMAN,P.M. and JOSEFOWICZ,W.J. (1978). Oocyte development in the mouse: an ultrastructural comparison of oocytes isolated at various stages of growth and meiotic competence. J Morphol 156; 209-235.

WEIL,M., JACOBSON,M.D., COLES,H.S., DAVIES,T.J., GARDNER,R.L., RAFF,K.D. and RAFF,M.C. (1996). Constitutive expression of the machinery for programmed cell death. J Cell Biol 133; 1053-1059.

WIESNER,R.J., ZSURKA,G. and KUNZ,W.S. (2006). Mitochondrial DNA damage and the aging process: facts and imaginations. Free Radic Res 40; 1284-1294.

WONG-RILEY,M.T. (1989). Cytochrome oxidase: an endogenous metabolic marker for neuronal activity. Trends Neurosci 12; 94-101.

WREDENBERG,A., WIBOM,R., WILHELMSSON,H., GRAFF,C., WIENER,H.H., BURDEN,S.J., OLDFORS,A., WESTERBLAD,H. and LARSSON,N.G. (2002). Increased mitochondrial mass in mitochondrial myopathy mice. Proc Natl Acad Sci USA 99: 15066-15071.

XU,B. and CLAYTON,D.A. (1992). Assignment of a yeast protein necessary for mitochondrial transcription initiation. Nucleic Acids Res 20: 1053-1059.

YAN,Z.H., ZHOU,Y.Y., FU,J., JIAO,F., ZHAO,L.W., GUAN,P.F., HUANG,S.Z., ZENG,Y.T. and ZENG,F. (2010). Donor-host mitochondrial compatibility improves efficiency of bovine somatic cell nuclear transfer. BMC Dev Biol 10: 31

YANG,C.X., HAN,Z.M., WEN,D.C., SUN,Q.Y., ZHANG,K.Y., ZHANG,L.S., WU,Y.Q., KOU,Z.H. and CHEN,D.Y. (2003). In vitro development and mitochondrial fate of macaca-rabbit cloned embryos. Mol Reprod Dev 65: 396-401.

YASUKAWA, T., REYES,A, CLUETT, T.J, YANG,M.Y, BOWMAKER,M. JACOBS,H.T. and HOLT,I.J. (2006). Replication of vertebrate mitochondrial DNA entails transient ribonucleotide incorporation throughout the lagging strand. EMBO J 25: 5358-5371.

YASUKAWA,T., YANG,M.Y., JACOBS,H.T. and HOLT,I.J. (2005). A bidirectional origin of replication maps to the major noncoding region of human mitochondrial DNA. Mol Cell 18: 651-662.

ZHONG,Z, HAO,Y, LI,R, SPATE,L, WAX,D, SUN,QY, PRATHER,R S and SCHATTEN,H. (2008). Analysis of heterogeneous mitochondria distribution in somatic cell nuclear transfer porcine embryos. Microsc Microanal 14: 418-432.

ZHONG,Z., SPATE,L., HAO,Y., LI,R., LAI,L., KATAYAMA,M., SUN,Q.Y., PRATHER,R.S. and SCHATTEN,H. (2007). Remodeling of centrosomes in intraspecies and interspecies nuclear transfer porcine embryos. Cell Cycle 6: 1510-1520. 
Further Related Reading, published previously in the Int. J. Dev. Biol.

See our recent Special Issue Placenta edited by Joan S. Hunt and Kent L. Thornburg at: http://www.ijdb.ehu.es/web/contents.php?vol=54\&issue=2-3

Sperm mitochondria diaphorase activity - a gene mapping study of recombinant inbred strains of mice Aniela Golas, Paulina Malek, Malgorzata Piasecka and Jozefa Styrna Int. J. Dev. Biol. 54: 667 - 673 (2010)

The 2-cell block occurring during development of outbred mouse embryos is rescued by cytoplasmic factors present in inbred metaphase II oocytes

Mario Zanoni, Silvia Garagna, Carlo A. Redi and Maurizio Zuccotti Int. J. Dev. Biol. 53: 129 - 134 (2009)

Centrold, a novel putative DEAD-box RNA helicase maternal mRNA, is localised in the mitochondrial cloud in Xenopus laevis oocytes

Malgorzata Kloc and Agnes P. Chan

Int. J. Dev. Biol. 51: 701-706 (2007)

Mammalian oocyte activation: lessons from the sperm and implications for nuclear transfer.

R Alberio, V Zakhartchenko, J Motlik and E Wolf

Int. J. Dev. Biol. 45: 797 - 809 (2001)

Localization of mitochondrial large rRNA in germinal granules and the consequent segregation of germ line.

S Kobayashi, R Amikura and M Okada

Int. J. Dev. Biol. 38: 193 - 199 (1994)

Mitochondrial DNA content and mitochondrial gene transcriptional activities in the early development of loach and goldfish. Int. J. Dev. Biol.Ä36: 477 - 482 (1992)

G Wang and S Yan

5 yr ISI Impact Factor $(2009)=3.253$

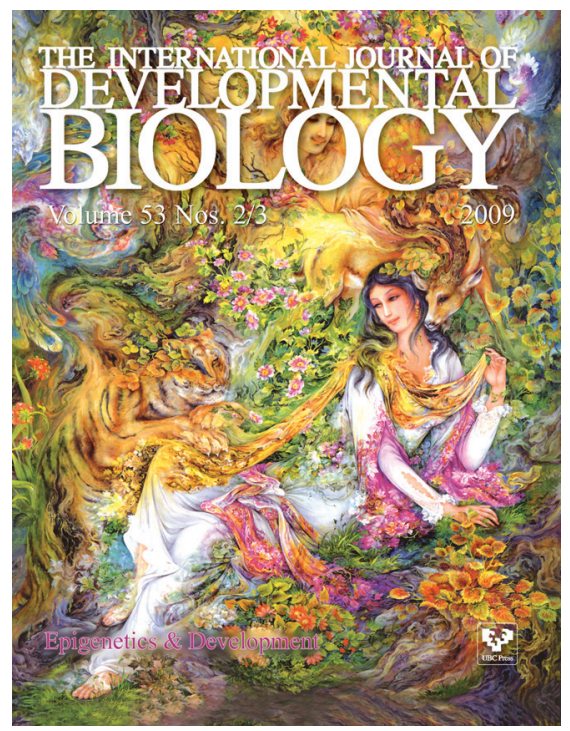

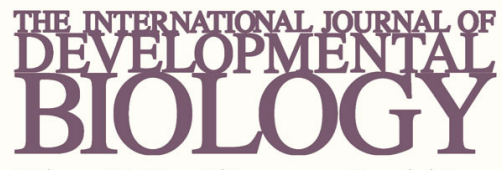

Volume 54 Nos. 6/7
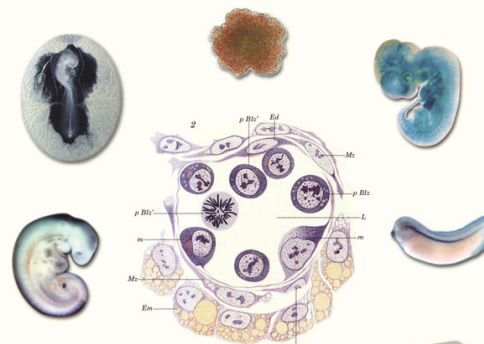

Developmental Hematopoiesis

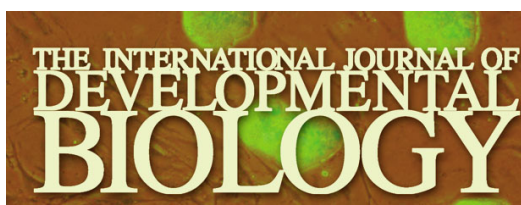

Volume 54 Nos. 11/12

Special Issue

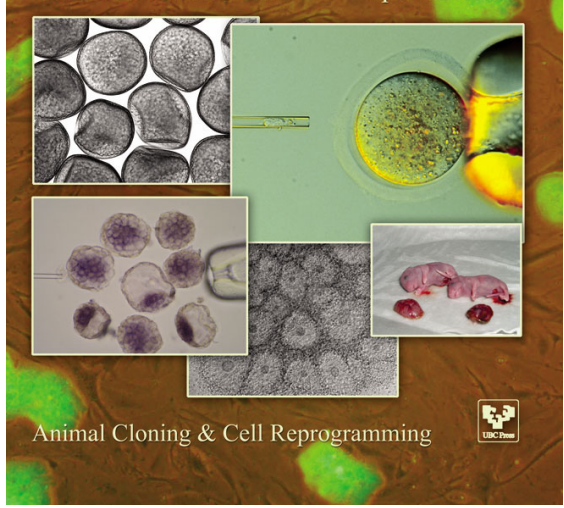

